\title{
Breeding productivity, nest-site selection and conservation needs of the endemic Turkestan Ground-jay Podoces panderi
}

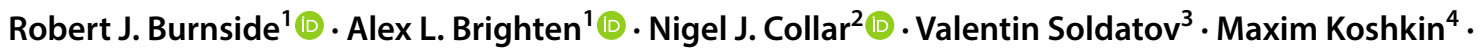 \\ Paul M. Dolman' ${ }^{1}$. Anna Ten ${ }^{5}$
}

Received: 23 January 2020 / Revised: 27 March 2020 / Accepted: 19 May 2020 / Published online: 1 June 2020

(c) The Author(s) 2020

\begin{abstract}
The Turkestan Ground-jay Podoces panderi, a corvid endemic to the deserts of Central Asia, is both understudied and underprotected. Using standardised nest-monitoring protocols and nest cameras, we estimated its breeding productivity for the first time as 0.586 fledglings per nesting attempt (inter-quartile range, IQR $0.413-0.734$ ), strongly constrained by a diverse set of predator species (accounting for $88 \%$ of failures), supporting the broad pattern that a wide spectrum of nest predators operate in arid environments. The probability of nest success for the 35 days from the start of incubation to fledging was low, $0.186 \pm 0.06 \mathrm{se}(N=37)$, with no influence of season date, nest height or nest shrub species. However, pervasive shrub harvest severely limited availability of taller shrubs for nest-site selection, and thus our ability to detect any effect of height on nest survival. Mean clutch size was $4.8 \pm 0.8 \mathrm{sd}$ while hatching probability of an egg from a clutch surviving incubation was $0.800 \pm 0.050$ se and fledging probability was $0.824 \pm 0.093 \mathrm{se}$ for individual chicks in successful nests (i.e. that fledged one or more chicks). Two shrub genera, saxaul Haloxylon spp. and Calligonum spp., were used for nesting more frequently than expected $\left(\chi_{15}^{2}=784.02, P<0.001\right)$, highlighting their importance to breeding habitat suitability. This near-sole reliance on these taller shrub genera, both targeted for illegal cutting, indicates that habitat degradation may lead to increased predation and declines in productivity. Habitat conservation is, therefore, likely to be the most important management strategy for the species and other components of desert systems, as management of so diverse a set of nest predators would be both impractical and inappropriate.
\end{abstract}

Keywords Kyzylkum desert · Nest success · Fledging success $\cdot$ Nest predation $\cdot$ Saxaul Ground-jay $\cdot$ Pander's Ground-jay

\section{Zusammenfassung}

\section{Brutproduktivität, Nistplatzwahl und Schutzbedarf des endemischen Saxaulhähers Podoces panderi}

Der Saxaulhäher Podoces panderi, ein in den zentralasiatischen Wüsten endemischer Rabenvogel, ist weder hinreichend untersucht noch hinreichend geschützt. Mit Hilfe standardisierter Nestbeobachtungsprotkolle und Nestkameras haben wir seine Brutproduktivität erstmalig auf 0,586 Flügglinge pro Brutversuch geschätzt (Interquartilsabstand IQR 0,413-0,734). Die Produktivität war stark durch eine Reihe verschiedener Prädatoren, die für $88 \%$ der Nestverluste verantwortlich waren,

Communicated by O. Krüger.

Electronic supplementary material The online version of this article (https://doi.org/10.1007/s10336-020-01790-9) contains supplementary material, which is available to authorized users.

Robert J. Burnside

robertjohnburnside@hotmail.com

1 School of Environmental Sciences, University of East Anglia, Norwich Research Park, Norwich, Norfolk NR4 7TJ, UK

2 BirdLife International, Pembroke Street, Cambridge CB2 3QZ, UK
3 A.Kodyrov str.-2/54, Tashkent, Uzbekistan

4 Ilbirs Foundation, 1/45 Tynaliev Str, Bishkek 720038, Kyrgyz Republic

5 Institute of Zoology of Academy of Science of Uzbekistan, Bogi-Shamol str.-232B, Tashkent, Uzbekistan 
eingeschränkt, was das allgemeine Muster bestätigt, dass in ariden Umwelten ein breites Spektrum von Nestprädatoren agiert. Die Bruterfolgswahrscheinlichkeit in den 35 Tagen vom Bebrütungsbeginn bis zum Ausfliegen war mit 0,186 ( $\pm 0,06$, $N=37$ ) niedrig und wurde nicht vom Brutdatum, der Höhe des Nestes oder der Gehölzart am Neststandort beeinflusst. Die allgegenwärtige Gehölzernte limitierte jedoch stark die Verfügbarkeit höherer Gehölze für die Nistplatzwahl und damit unsere Fähigkeit, einen statistischen Effekt der Nesthöhe auf das Überleben des Nests festzustellen. Die mittlere Gelegegröße betrug 4,8 ( $\pm 0,8)$, während die Schlupfwahrscheinlichkeit eines Eis aus einem Gelege, welches das Bebrütungsstadium überlebte, 0,800 ( $\pm 0,050)$ und die Ausfliegewahrscheinlichkeit einzelner Kükens aus erfolgreichen Nestern (d.h. solchen, aus denen mindestens ein Küken ausflog) 0,824 ( \pm 0,093) betrugen. Zwei Gehölzgattungen, Saxaul Haloxylon spp. und Calligonum spp., wurden häufiger als erwartet als Neststandort gewählt $\left(\mathrm{chi}^{2}=784.02, P<0.001\right)$, was ihre Bedeutung für die Eignung eines Habitats zum Nisten unterstreicht. Die nahezu vollständige Abhängigkeit von diesen hochgewachsenen Gehölzgattungen, die beide illegalem Gehölzschnitt ausgesetzt sind, deutet darauf hin, dass Habitatdegradierung zu verstärkter Prädation und Abnahme der Produktivität führen kann. Daher ist Habitaterhaltung wahrscheinlich die wichtigste Managementstrategie für diese Vogelart und andere Komponenten von Wüstensystemen, da das Management einer so diversen Gruppe von Nestprädatoren sowohl unpraktisch als auch unangemessen wäre.

\section{Introduction}

Ground-jays of the genus Podoces are a distinct group of four corvid species inhabiting arid to semi-arid landscapes in Asia. All four are poorly studied, doubtless because of the remoteness and inhospitability of their habitats: of 43 sources for the species accounts by Madge (2009), only 10 are species-specific studies. They are also poorly protected: although three species have the IUCN status Least Concern and one Near Threatened (BirdLife International 2019), Madge (2009) inferred declines in all four, attributable to habitat loss from various combinations of mining, overgrazing, agriculture, firewood-gathering, water extraction and roads. Here we report the first detailed study of the breeding productivity of the Turkestan Ground-jay Podoces panderi (Supporting Online Information Fig. S1) and consider the implications for its conservation management.

Turkestan Ground-jay is endemic to the Turkestan region of Central Asia, with a patchy distribution in eastern and southern Kazakhstan, central Uzbekistan, and Turkmenistan (Fig. 1 inset) inhabiting the region's temperate deserts, in part formed by the Kyzylkum and Karakum deserts (Madge 2009). Except for a tiny outlying population in eastern Kazakhstan (Kovshar 2015) there is no recent information on the species' demography or status. A mere $5.6 \%$ of its range is protected (Supporting Online Information Fig. S2: World Database on Protected Areas 2019), and it only appears in the national red list of Kazakhstan (Kovshar 2010) but not Uzbekistan (Azimov et al. 2009) or Turkmenistan (Annabayramov 2011). Although judged to be 'declining' based on general impressions of habitat loss (Madge and Burn 1993; Madge 2009), Turkestan Ground-jay is classified globally as Least Concern (BirdLife International 2019).

To begin to clarify the conservation status of the species, we studied nest survival, causes of nest failure, and nest shrub choice in a core part of its range in southern Uzbekistan. No studies of its nesting biology have been conducted since the 1980s (reviewed in Rustamov 1958, Lanovenko 1995, Kovshar 2015), and earlier work did not report overall nest success probability (Lakhanov 1977) but noted that predation was the main cause of nest failure. We hypothesised that risk of predation and hence nest daily survival rate (DSR) would be influenced by season date (emergence of predators with date: Koshkin et al. 2016a), nest shrub species and nest height (Guan et al. 2018; Guilherme et al. 2018).

\section{Materials and methods}

\section{Study area and species}

The study was conducted in the southern Kyzylkum Desert in Bukhara province, Uzbekistan $\left(39.34-40.56^{\circ} \mathrm{N}\right.$, $62.21-65.20^{\circ}$ E, Fig. 1), in an area known for its high spring numbers of Turkestan Ground-jays (Showler et al. 2014). Here, Turkestan Ground-jays occur primarily on areas with sand cover and heterogeneous shrub assemblages dominated by Calligonum spp., Astragalus spp., Salsola rigida and $S$. arbuscula, but are absent from Artemisia-dominated desert on clay (Showler et al. 2014). White Haloxylon persicum and black H. aphyllum saxaul occur sporadically throughout these habitats. Saxaul forestry plantations were established during the Soviet era for fuel and to stabilise the sand, but have been extensively cleared from the desert through illegal cutting for home heating during winter. Saxaul continues to be planted and managed to provide fuelwood for traditional tandyr bread cooking and heating, but new plantations are subject to earlier harvest and illegal cutting (AT and MK pers. obs.). Koshkin et al. (2014, 2016a, b) and Guilherme et al. (2018) give further details of shrub habitat structure and composition.

Between February and June Turkestan Ground-jay constructs a relatively conspicuous cup nest in a shrub using 

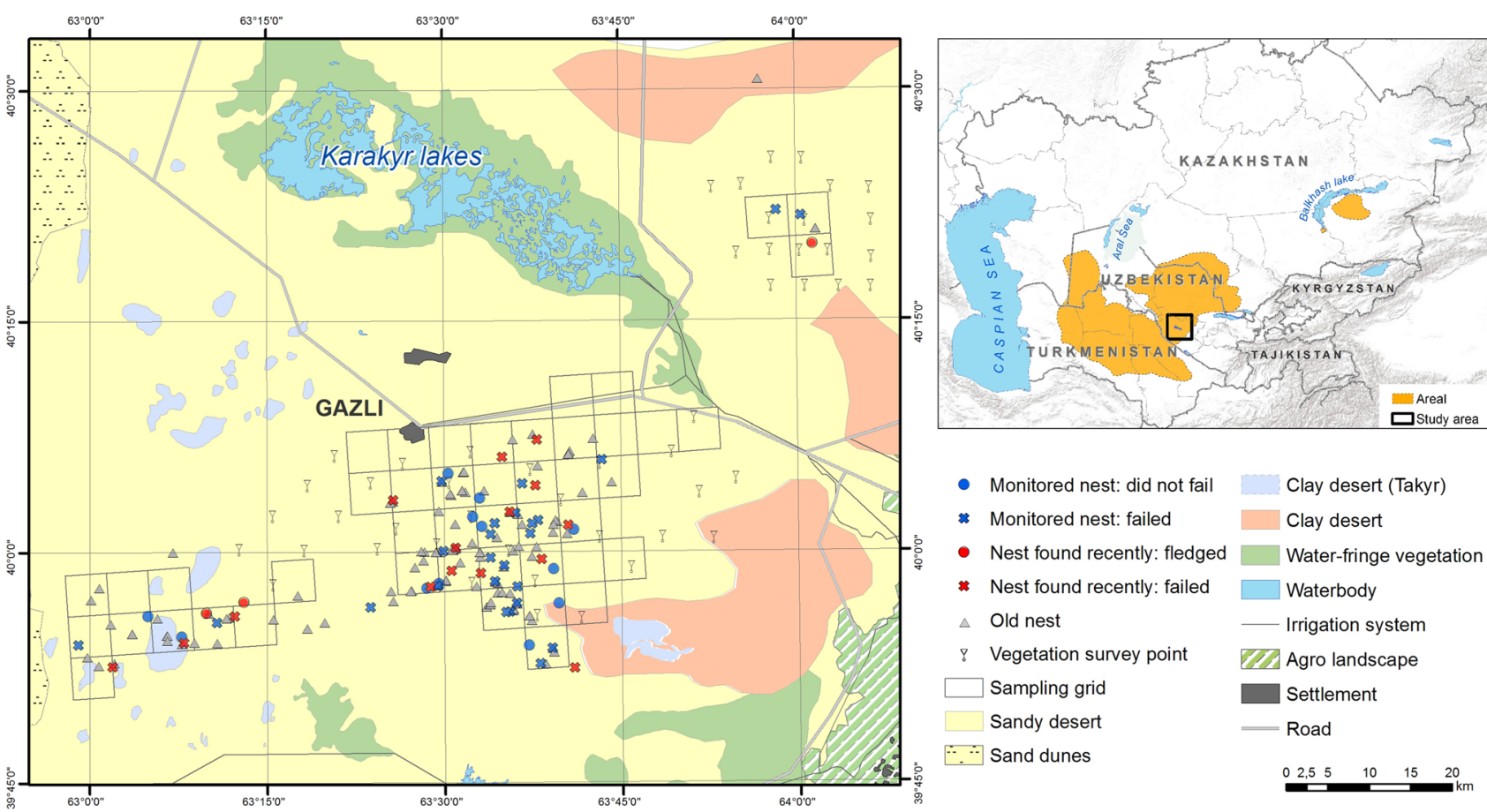

Fig. 1 Map of Turkestan Ground-jay nests found in Bukhara province, Uzbekistan, 2019. Symbols denote the outcome of the nest and whether it was active when found. Vegetation sampling points are shown

intertwined twigs (lined with animal hair/wool), with a rudimentary roof of longer pale twigs (Fig. 2). The species is apparently single-brooded, laying a clutch of 3-7 eggs with an incubation period of $16-19$ days (mean $\approx 18$ days) and a nestling period of 17 days; the female incubates and is fed by the male, but both parents feed the chicks (Madge 2009, 2019).

\section{Nest searching and monitoring}

We searched for nests within 45 grid-squares (each $5 \mathrm{~km} \times 5 \mathrm{~km}$, Fig. 1) between 13 April and 12 May 2019, and monitoring continued to 5 June. Grid-squares (spanning c. $120 \mathrm{~km}$ east to west and c. $50 \mathrm{~km}$ north to south) were searched by driving along pre-existing tracks. Search effort was recorded as the time spent searching (median time per square $=1.4 \mathrm{~h}$, inter-quartile range [IQR $] 1-3.5 \mathrm{~h}$ ) to estimate encounter rates for future comparisons with different areas or years. Nests were located by two methods. First, when ground-jays were thought to be displaying nesting behaviour (showing agitation, making alarm calls and attempting to distract the observer), the vehicle was stopped and bushes scanned (for no longer than $30 \mathrm{~min}$, to curtail disturbance). Second, areas were scanned when an elevated vantage point was available, as such sites made it possible to observe birds foraging and returning to the nest. Nests were classified as active, successfully hatched, fledged or failed, by visits at five-day intervals. A subset of 18 nests (48.6\%) were fitted with nest cameras to establish predator identity; further details of nest searching and monitoring protocols are in Supporting Online Information Appendix 1.

\section{Nest shrub preference}

Nest shrub species choice (observed nests) was related by a $\chi^{2}$ test to the local shrub species composition within $5 \mathrm{~km}$ of the study grid-squares (Fig. 1), using 2895 observations from 18 shrub species (Table 1) sampled at 49 points (data from Koshkin et al. 2016a). Congener pairs with the similar morphological structure were pooled ('halsp': Haloxylon aphyllum and H. persicum; 'astsp': Astragalus villosissimus and A. unifoliolatus; 'calsp': Calligonum leucocladum and C. microcarpum), yielding 16 morpho-groups (Table 1) for analysis of nest site placement.

\section{Analysis of breeding productivity}

Nest daily survival rate (DSR) was calculated as 1-daily risk of nest failure, modelled as nest outcome (coded: failure $=1$; success $=0$ ) relative to nest-specific number of exposure days monitored, following Mayfield (1975). Only active nests (containing eggs or chicks) were included in nest survival analysis; for nests with no eggs (which may have been under construction, or alternatively old, failed or 

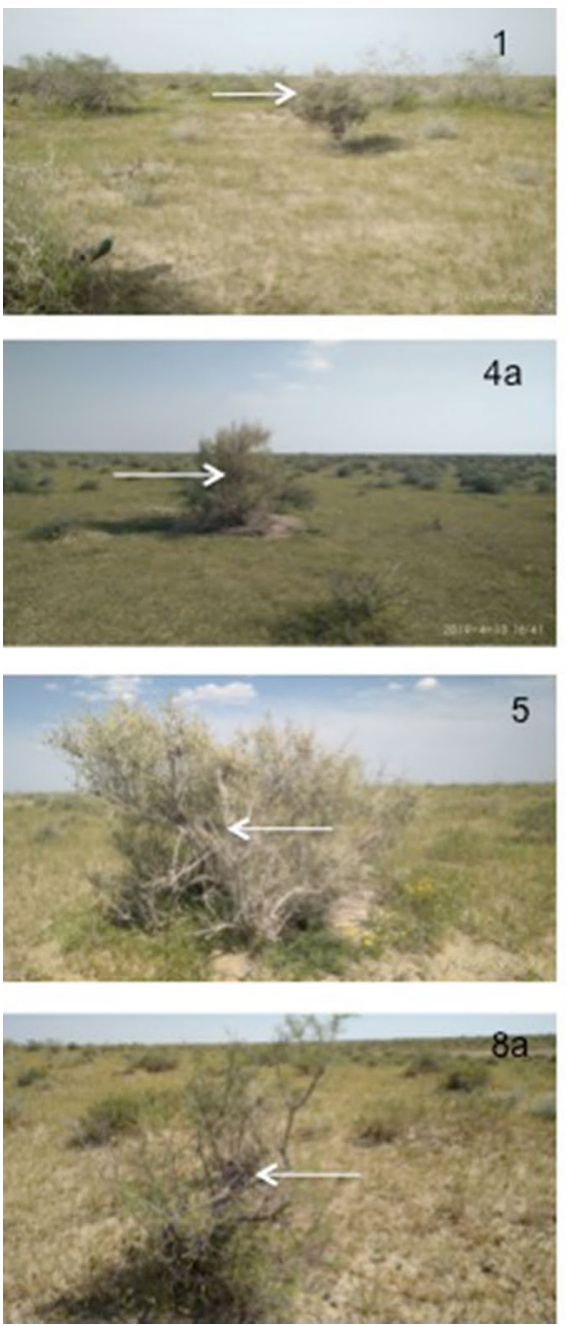

2
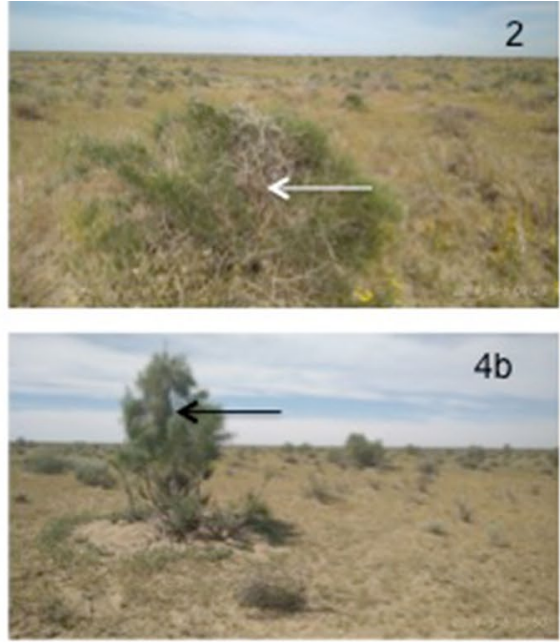

6
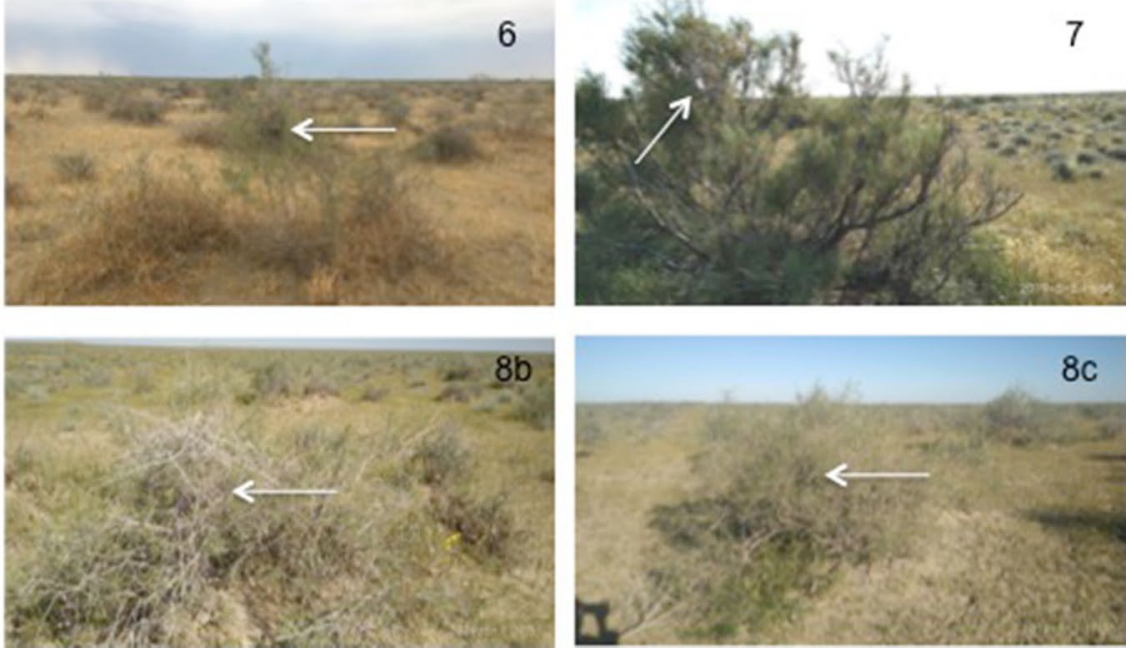
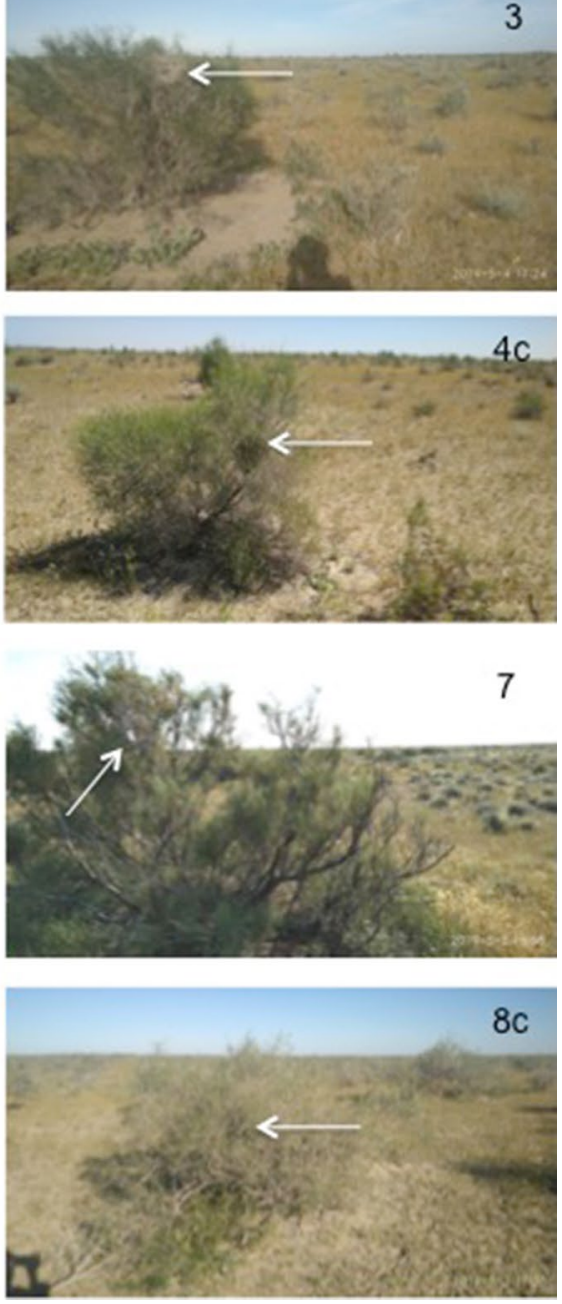

Fig. 2 Examples of Turkestan Ground-jay nests (marked by arrows) found in the Kyzylkum Desert, Uzbekistan, in spring 2019, on each of the eight different shrub species identified in the study: 1. Astragalus unifoliolatus; 2. Calligonum sp.; 3. Haloxylon persicum; 4.
Haloxylon aphyllum; 5. Ephedra strobilacea; 6. Salsola richteri; 7. Tamarix sp.; 8. Salsola arbuscula. Examples of nest-roofs can be seen in 2,3 and $8 b$

('date'), nest height (continuous, from the ground to base of the nest) and nest shrub species on DSR for the entire nesting period $\left(S_{\text {nest }}\right)$ only. We constructed models in RMARK (8.2; White and Burnham 1999), allowing DSR to vary with date and date ${ }^{2}$ (Dinsmore et al. 2002). We considered a covariate to be supported if its addition decreased the Akaike Information Criterion (corrected for small sample size: AICc) by at least two units (Burnham and Anderson 2002). For DSR analysis, the 16 shrub morpho-species groups were further simplified: Astragalus spp., Tamarix spp., Salsola richteri and Ephedra strobilacea were pooled as 'other' owing to the low sampled occurrence, resulting in four groups (Table 1).

Hatching rate (of eggs laid) in a successful clutch $\left(S_{\text {hatch }}\right)$ and fledging rate (of hatched chicks) in a successful brood $\left(S_{\text {fledge }}\right)$ (Table 1$)$ were calculated using intercept-only GLMs with binomial error, coding outcomes as hatched/fledged $=1$; 
Table 1 Shrub species' abbreviations, and frequency in sampling from the Kyzylkum Desert, Bukhara province, Uzbekistan, with Turkestan Ground-jay nest shrub species in bold

\begin{tabular}{|c|c|c|c|c|}
\hline Species & $\begin{array}{l}\text { Nest site } \\
\text { preference } \\
\text { groups }\end{array}$ & $\begin{array}{l}\text { Nest survival } \\
\text { groups (DSR } \\
\text { analysis) }\end{array}$ & $\begin{array}{l}\text { Frequency of } 2019 \text { nests in } \\
45 \text { survey squares, number } \\
(\%)\end{array}$ & $\begin{array}{l}\text { Frequency at } 49 \text { sampling points } \\
\text { (from Koshkin et al. 2016a), number } \\
(\%)\end{array}$ \\
\hline Acanthophyllum borszczowii & abor & & $0(0)$ & $29(1)$ \\
\hline Artemisia diffusa & adif & & $0(0)$ & $215(7)$ \\
\hline Alhagi pseudalhagi & apse & & $0(0)$ & $67(2)$ \\
\hline $\begin{array}{l}\text { Astragalus spp. (A. villosissimus }+A . \\
\text { unifoliolatus) }\end{array}$ & astsp & other & $2(4)$ & 340 (12) \\
\hline Aellenia subaphylla & asub & & $0(0)$ & $6(0)$ \\
\hline Calligonum spp. & calsp & calsp & $14(25)$ & $157(5)$ \\
\hline Convolvulus hamadae & cham & & $0(0)$ & $468(16)$ \\
\hline Dead shrub (various species) & dead & & $0(0)$ & $533(18)$ \\
\hline Ephedra strobilacea & estr & other & $4(7)$ & $1(\mathbf{0})$ \\
\hline $\begin{array}{l}\text { Haloxylon spp. (H. aphyllum }+H . \\
\text { persicum) }\end{array}$ & halsp & halsp & $23(42)$ & $37(1)$ \\
\hline Mausolea eriocarpa & meri & & $0(0)$ & $15(1)$ \\
\hline Salsola arbuscula & sarb & sarb & $9(16)$ & $429(15)$ \\
\hline Salsola gemmascens & sgem & & $0(0)$ & $121(4)$ \\
\hline Salsola richteri & sric & other & $1(2)$ & $92(3)$ \\
\hline Salsola rigida & srig & & $0(0)$ & $385(13)$ \\
\hline Tamarix spp. & tamsp & other & $2(4)$ & $\mathbf{0}(\mathbf{0})$ \\
\hline TOTAL & & & $55(100)$ & $2895(98)$ \\
\hline
\end{tabular}

failed $=0$ and treating each egg/chick within a clutch/brood as an independent event (Aebischer 1999). Breeding productivity (number of fledglings per nesting attempt) was calculated as: $\mathrm{N}_{\text {clutch }} \times \mathrm{S}_{\text {nest }} \times \mathrm{S}_{\text {hatch }} \times \mathrm{S}_{\text {fledge }}$, resampling each parameter 1000 times (based on the observed mean and variance) to create a distribution of breeding productivities.

All modelling, statistics and simulations were carried out using R version 3.6.1 (R Core Team 2019).

\section{Results}

\section{Encounter rate}

During $146 \mathrm{~h}$ of nest-searching effort, we made 236 Turkestan Ground-jay observations (1.6 ground-jays $\left.{ }^{- \text {hour }}\right)$. Of 178 nests located, 55 were judged new in 2019, with 37 active during the monitoring period. Of these, 12 were new nests found prior to laying (empty but undamaged roofed structures internally lined with camel hair, with fresh droppings below), but held eggs on a second visit, while 22 held eggs and three held nestlings when found.

\section{Nest shrub preference}

Nine species of shrub (7 groups) were used for the 55 nests in 2019 (Table 1). Used-shrub frequency differed from that available $\left(\chi_{15}^{2}=784.02, P<0.001\right)$, with saxaul Haloxylon, Calligonum and Tamarix spp. used more and Astragalus less than random (Table 1). The nine other shrub species in the area were not used for nests (Table 1). Mean nest height was only $60.2 \pm 32.0$ (sd) cm (range 15-143 cm, $n=55$, Supporting Online Information Fig. S3).

\section{Breeding parameters}

All breeding parameters are shown in Table 2. First egg laydates, estimated for 27 nests, ranged from 3 April to 20 May, mean 25 April. Mean clutch size was $4.8 \pm 0.8 \mathrm{sd}(n=30)$ (Table 2).

Of 37 active nests found, 34 were monitored during incubation, of which 19 failed, one was still being incubated when monitoring ended, and 14 hatched to be included in the nestling stage. Three more nests were found with chicks, giving a total of 17 broods monitoring during the nestling stage, of which six failed, five were still active when monitoring ended and six fledged. DSR did not differ between incubation and nestling periods $(\mathrm{Z}=-0.611, p=0.541$, Table 2). Overall nest success $\left(S_{\text {nest }}\right)$ was $0.186 \pm 0.063$ se $(n=37)$ with no support for any influence of date, date ${ }^{2}$, nest height or shrub species on DSR, as no covariate or combination of covariates improved model performance relative to the null model (Table 3). Number of eggs hatching in a clutch was confirmed for 13 successfully hatched nests, 
Table 2 Breeding parameter estimates with survival analysis by Mayfield's estimator of daily survival rate (DSR) of Turkestan Ground-jay nests in the southern Kyzylkum Desert, Bukhara province, Uzbekistan, in the 2019 breeding season

\begin{tabular}{|c|c|c|c|}
\hline Breeding parameter & Details & $\begin{array}{l}\text { Sample } \\
\text { size of } \\
\text { nests }\end{array}$ & Parameter estimate \\
\hline Mean clutch size $\left(N_{\text {clutch }}\right)$ & Confirmed completed clutches (stable across two visits) & 30 & $4.8 \pm 0.76$ sd (range $3-6)$ \\
\hline Nest success $\left(S_{\text {nest }}\right)$ & $\begin{array}{l}\text { Probability of survival from start of incubation to fledg- } \\
\text { ing }\end{array}$ & 37 & $\begin{array}{l}\mathrm{DSR}=0.953 \pm 0.009 \\
\text { Overall } 35 \text { days }=0.186 \pm 0.060 \mathrm{se}\end{array}$ \\
\hline Incubation success $\left(S_{\text {incubation }}\right)$ & $\begin{array}{l}\text { Probability of survival from start of incubation to hatch- } \\
\text { ing }\end{array}$ & 34 & $\begin{array}{l}\text { DSR } 0.950 \pm 0.011 \\
\text { Overall } 18 \text { days }=0.397 \pm 0.084 \mathrm{se}\end{array}$ \\
\hline Nestling success $\left(S_{\text {nestling }}\right)$ & Probability of survival from hatching to fledging & 17 & $\begin{array}{l}\mathrm{DSR}=0.962 \pm 0.015 \\
\text { Overall } 17 \text { days }=0.517 \pm 0.139 \mathrm{se}\end{array}$ \\
\hline Egg hatchability $\left(S_{\text {hatch }}\right)$ & Probability an egg will hatch within a successful nest & 13 & $0.800 \pm 0.050 \mathrm{se}$ \\
\hline Chicks fledged $\left(S_{\text {fledge }}\right)$ & Probability a chick will fledge within a successful nest & 5 & $0.824 \pm 0.093 \mathrm{se}$ \\
\hline Productivity & $\begin{array}{l}\text { mean fledglings per nesting attempt }=\mathrm{N}_{\text {clutch }} \times \mathrm{S}_{\text {nest }} \times \\
\mathrm{S}_{\text {hatch }} \times \mathrm{S}_{\text {fledge }}\end{array}$ & & 0.586 (inter-quartile range: $0.413-0.734$ ) \\
\hline
\end{tabular}

Table 3 Models of Turkestan Ground-jay nest survival from 37 nests (combining egg and chick periods) monitored in Bukhara province of Uzbekistan in 2019, showing model degrees of freedom $(d f)$, log-likelihood (logLik), AICc and change $(\Delta)$ relative to the null (interceptonly) model

\begin{tabular}{|c|c|c|c|c|c|}
\hline Model & $d f$ & $\log \operatorname{Lik}$ & $\mathrm{AICc}$ & $\Delta \mathrm{AICc}$ & Model weight \\
\hline Null & 1 & -33.28 & 68.58 & 0.00 & 0.20 \\
\hline Date & 2 & -32.86 & 69.77 & 1.19 & 0.11 \\
\hline Shrub type & 4 & -30.96 & 70.07 & 1.49 & 0.10 \\
\hline Date $^{2}$ & 2 & -33.04 & 70.12 & 1.54 & 0.09 \\
\hline Nest height & 2 & -33.06 & 70.16 & 1.58 & 0.09 \\
\hline Date + Date $^{2}$ & 3 & -32.18 & 70.46 & 1.88 & 0.08 \\
\hline Nest height + Shrub type & 5 & -30.51 & 71.25 & 2.67 & 0.05 \\
\hline Nest height + Date & 3 & -32.79 & 71.67 & 3.09 & 0.04 \\
\hline Nest height + Date $^{2}$ & 3 & -32.93 & 71.96 & 3.38 & 0.04 \\
\hline Shrub type + Time & 5 & -30.89 & 72.02 & 3.44 & 0.04 \\
\hline Shrub type + Date $^{2}$ & 5 & -30.95 & 72.13 & 3.55 & 0.03 \\
\hline Nest height + Date + Date $^{2}$ & 4 & -32.03 & 72.21 & 3.63 & 0.03 \\
\hline Shrub type + Date + Date $^{2}$ & 6 & -30.19 & 72.71 & 4.13 & 0.03 \\
\hline Nest height + Date $^{2}$ & 6 & -30.50 & 73.33 & 4.74 & 0.02 \\
\hline Nest height + Shrub type + Date & 6 & -30.50 & 73.33 & 4.75 & 0.02 \\
\hline Nest height + Shrub type + Date + Date $^{2}$ & 7 & -29.51 & 73.46 & 4.88 & 0.02 \\
\hline
\end{tabular}

giving an $S_{\text {hatch }}=0.800 \pm 0.050$ se. Number of chicks fledged was estimated from five nests (three confirmed on camera and two from observing broods near the nest): at least 14 chicks fledged from 17 hatched eggs, giving a minimum estimated mean of $S_{\text {fledge }} 0.824 \pm 0.093$ se. Overall, breeding productivity was 0.586 (IQR $0.413-0.734$ ) fledglings per nesting attempt.

\section{Causes of failure}

Twenty-five nests failed (Table 4). Twenty-two of these (88\%) were predated, and one each was destroyed by human agency (4\%), abandoned (4\%) and lost to unknown causes
(4\%). Nest cameras identified five predator species: Red Fox Vulpes vulpes, Desert Monitor Varanus griseus, Asiatic Wildcat Felis lybica, Diadem Snake Spalerosophis diadema and Long-eared Hedgehog Hemiechinus auritus (Table 4, Supporting Online Information Fig. S4 and Video 1). Red Fox and Desert Monitor jointly accounted for $57 \%$ of predations. The high rate of failure was further evidenced by 18 nests that were discovered empty and not included in the survival analysis but were suspected to have been built and active in 2019 (indicated by fresh nest-lining, droppings and nest-roofs); evidence of predation was lacking at three (16.7\%) but apparent at $15(83.3 \%)$, indicated by broken or abandoned eggs and/or damaged structure. 
Table 4 Causes of failure of Turkestan Ground-jay nests confirmed by nest camera or inferred using field signs from the 2019 breeding season in the Kyzylkum Desert, Uzbekistan

\begin{tabular}{llll}
\hline Cause of failure & $\begin{array}{l}\text { Number confirmed } \\
\text { on camera }\end{array}$ & $\begin{array}{l}\text { Number inferred from } \\
\text { field signs }\end{array}$ & $\begin{array}{l}\text { Mini- } \\
\text { mum } \\
\text { total }\end{array}$ \\
\hline Unidentified predator & 2 & 9 & 11 \\
Red Fox Vulpes vulpes & 3 & 3 & 6 \\
Desert Monitor Varanus griseus & 2 & 0 & 2 \\
Asiatic Wildcat Felis lybica & 1 & 0 & 1 \\
Long-eared Hedgehog Hemiechinus auritus & 1 & 0 & 1 \\
Diadem Snake Spalerosophis diadema & 1 & 0 & 1 \\
Destruction by humans & 0 & 1 & 1 \\
Unknown cause & 1 & 0 & 1 \\
Abandoned & 1 & 0 & 1 \\
\hline
\end{tabular}

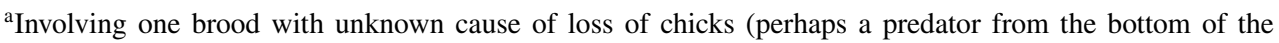
nest)

\section{Discussion}

The high nest predation rate reported here ( $88 \%$ of failed nests) is consistent with rates (85\%) across five species of semi-arid desert passerine (Mezquida 2004). Overall nest success rates (18.6\%) were similar to the Iranian Groundjay Podoces pleskei, which had nest success probabilities in Zygophyllum eurypterum dominated shrublands varying from 13 to $36 \%$ between years and regions (Radnezhad et al. 2011). We found no effect of the date on nest survival but acknowledge this may have been influenced by the small sample of nests and the limited sampling period, which started in mid-April when nest predator activity had already reached a maximum (see Koshkin et al. 2016a). Turkestan Ground-jays can complete clutches in midMarch (Showler et al. 2014), and early nesters may, therefore, avoid predators such as desert monitors, snakes and hedgehogs, which emerge from hibernation in early April (Koshkin et al. 2016a).

We found no effect of nest height or shrub species on nest success. However, the absence of a height effect may be due to a lack of access to taller shrubs for nesting. Nests tended to be close to the ground $(60.2 \mathrm{~cm} \pm 32.0 \mathrm{sd})$ and accessible to most predators. Although saxaul can grow to $5 \mathrm{~m}$ (H. persicum) or even $10 \mathrm{~m}$ (H. aphyllum) (Gintzburger et al. 2003), their mean height within the study area was only $98 \mathrm{~cm} \pm 57$ (sd) (Koshkin unpub. data), presumably owing to the targeted collection of larger plants. It is, therefore, possible that the ground-jays in our study area were using suboptimal nesting substrates. However, the diverse range of predators, with different hunting methods, may confound any one particular nest defence strategy such as maximising nest height (Kozma et al. 2017). Interestingly the five species we identified are all new additions to the list of known nest predators of Turkestan Ground-jay, namely martens Martes, polecats Mustela,
Caracal Caracal caracal, crows Corvidae, eagles (presumably Aquila) and harriers Circus (Lakhanov 1977). Iranian Ground-jays lose nests to the same species as in our study but also to sheepdogs and sheep (Radnezhad et al. 2011), potentially reflecting the risk of nesting too close to the ground and perhaps, therefore, the degradation of habitat in the range of that species. When under pressure from multiple types of predator, general seclusion and avoidance may be the optimal tactic (Sih et al. 1998; Schmidt and Whelan, 1999); undoubtably the ground-jays' strong preference for the tall leafy saxaul reflects its potential to conceal or potentially protect a nest.

\section{Nest shrub preference}

All eight shrub species in which nests were found grow above $1 \mathrm{~m}$ in height and occur on loose sandy substrates. Ground-jays are largely absent from clay substrates in northern Bukhara province despite the presence there of saxaul clusters (Showler et al. 2014). This almost certainly reflects the birds' need for sandy substrates in which to dig for food (AT and RJB pers. obs.). The tallest shrubs present, saxaul Haloxylon spp., were chosen at 42 times their available rate, much greater than the next favoured and second-tallest shrubs, Calligonum spp., which were chosen five times more than available. Overall, these two genera (four species) comprised $68 \%$ of shrubs used for nesting. However, ground-jays tend to be absent from the densest stands of saxaul (RJB pers. obs.), perhaps because such habitat reduces visibility (Kovshar 2015). A diverse assemblage of different-sized shrub species may represent the optimal combination of habitat characteristics, with scattered tall shrubs providing look-out perches as well as nest sites but not obscuring views while foraging on the ground.

The removal of important nesting sites, particularly saxaul, may have a negative impact on ground-jay distribution and/or productivity. Collection of saxaul, Calligonum 
and Astragalus spp. for fuelwood is still widespread in Uzbekistan, and was frequently noted within the study area (Brighten and Burnside 2019). Preserving a heterogeneous habitat structure and older/larger shrub species such as saxaul, possibly through stricter control of fuelwood collection, is likely to be a key conservation measure for the ground-jay.

\section{Conservation implications}

A research initiative and status update are overdue for this endemic species to identify and define priorities for its management. A quarter of a century ago the ground-jay was judged to be decreasing due to habitat loss and fuelwood collection (Madge and Burn 1993). Its conservation status seems likely to have deteriorated since then, given widespread increases in mining, canal building, conversion of the desert to irrigated agriculture and the continuing collection of saxaul (Brighten and Burnside 2019). Our finding that the species has a breeding productivity strongly limited by nest predators and specific nesting habitat requirements suggests that it is likely to be sensitive to habitat degradation and conversion. Lack of solid information about its current status and the indication that $<6 \%$ of its range is under protected area management (Supporting Online Information Fig. S2) clearly highlight a need for a concerted research programme that can provide the evidence base for the long-term conservation of the species.

Studies of nest predation rates in temperate systems have revealed a wide range of avian and mammalian nest predators, but usually with few species responsible for most predation (e.g. Schaeffer 2004; Staller et al 2005; Thompson 2007; Teunissen et al 2008; Stevens et al 2008; Zielonka et al. 2020). The diverse range of predator species in arid and hot systems is steadily emerging (Mezquida 2004; Guilherme et al. 2018) and clearly suggests that managing breeding productivity through predator control would be both an unfeasible and an inappropriate response (ecologically and ethically). However, avian populations in relatively simple desert habitats are particularly vulnerable to habitat degradation (Iknayan and Beissinger 2018), which is likely to have a significant effect on breeding productivity by influencing both nest site availability and nest predation rates (Martin 1993; Ibáñez-Álamo et al. 2015; Pearce-Higgins et al. 2017). We conclude that habitat conservation is the most appropriate means of assuring the survival of the ground-jay and other components of desert systems.

Acknowledgements The Ornithological Society of the Middle East Conservation Fund and the University of East Anglia Environmental Sciences department together funded field transport. The Emirates Bird Breeding Center for Conservation gave logistical support, Dave Showler commented on the manuscript, and the Central Asian Desert
Initiative (CADI) contributed cameras for nest monitoring: https:// www.international-climate-initiative.com/en/nc/details/project/centr al-asian-desert-initiative-cadi-conservation-and-adaptive-use-of-winte r-cold-deserts-in-central-asia-16_IV_052-486/. We are grateful to two anonymous referees whose comments improved the final version of the paper.

Data availability statement The data that support the findings of this study are available in the supplementary material.

Open Access This article is licensed under a Creative Commons Attribution 4.0 International License, which permits use, sharing, adaptation, distribution and reproduction in any medium or format, as long as you give appropriate credit to the original author(s) and the source, provide a link to the Creative Commons licence, and indicate if changes were made. The images or other third party material in this article are included in the article's Creative Commons licence, unless indicated otherwise in a credit line to the material. If material is not included in the article's Creative Commons licence and your intended use is not permitted by statutory regulation or exceeds the permitted use, you will need to obtain permission directly from the copyright holder. To view a copy of this licence, visit http://creativecommons.org/licenses/by/4.0/.

\section{References}

Aebischer NJ (1999) Multi-way comparisons and generalized linear models of nest success: Extensions of the Mayfield method. Bird Study 46:S22-S31

Annabayramov B (2011) Volume 2: Invertebrate and Vertebrate Animals. The Red Book of Turkmenistan (third edition). Ministry of Nature Protection of Turkmenistan. Turkmenistan

Azimov JA, Umarov NM, Mirabdullayev IM, Khamrayev AS, Mirzayev UT, Chikin YA, Lanovenko EN, Mitropolskaya YO (2009) The Red Data Book of the Republic of Uzbekistan, Vol. II, Animals 2009. Chinor ENK, Tashkent

BirdLife International (2019) IUCN Red List for birds (genus Podoces). https://www.birdlife.org on 13 December 2019

Brighten AL, Burnside RJ (2019) Insights into the feeding ecology of and threats to Sand cat (Felis margarita thinobius) in the Kyzylkum Desert, Uzbekistan. J Threat Taxa 11:13492-13496

Burnham KP, Anderson DR (2002) Model selection and multimodel inference. A practical information-theoretic approach. Springer, New York

Dinsmore SJ, White GC, Knopf FL (2002) Advanced techniques for modelling avian nest survival. Ecology 83:3476-3488

Gintzburger G, Toderich KN, Mardonov BK, Mahmudov MM (2003) Rangelands of the Arid and Semi-arid Zones in Uzbekistan. CIRAD and ICARDA, Paris

Guan H, Wen Y, Wang P, Lv L, Xu J, Li J (2018) Seasonal increase of nest height of the Silver-throated Tit (Aegithalos glaucogularis): can it reduce predation risk? Avian Res 9:42

Guilherme JL, Burnside RJ, Collar NJ, Dolman PM (2018) Consistent nest-site selection across habitats increases fitness in Asian Houbara. Auk 135:192-205

Ibáñez-Álamo JD, Magrath RD, Oteyza JC, Chalfoun AD, Haff TM, Schmidt KA, Thomson RL, Martin TE (2015) Nest predation research: Recent findings and future perspectives. J Ornithol 156:247-262

Iknayan KJ, Beissinger SR (2018) Collapse of a desert bird community over the past century driven by climate change. PNAS 115:8597

Johnson DH (1979) Estimating nest success: the Mayfield method and an alternative. Auk 96:651-661 
Koshkin MA, Collar NJ, Dolman PM (2014) Do sheep affect distribution and habitat of Asian Houbara Chlamydotis macqueenii? J Arid Environ 103:53-62

Koshkin MA, Burnside RJ, Collar NJ, Guilherme JL, Showler DS, Dolman PM (2016a) Effects of habitat and land-use on breedingseason density of male Asian Houbara Chlamydotis macqueenii. J Ornithol 157:811-823

Koshkin MA, Burnside RJ, Packman CE, Collar NJ, Dolman PM (2016b) Effects of habitat and livestock on nesting success of the declining Asian houbara Chlamydotis macqueenii. Eur J Wildl Res 62:447-459

Kovshar AF (2010) Ili's Turkestan Ground jay. In: The red data book of the Republic of Kazakhstan, 4th edition, revised and updated. Volume I: Animals; Part 1: Vertebrates, pp 192-193. DPS, Almaty, Kazakhstan (in Russian)

Kovshar AF (2015) Turkestan [Pander's] Ground Jay (Podoces panderi J.G. Fischer, 1821): endemic species of Middle Asian deserts. Selevinia 23:9-32 (in Russian)

Kozma JM, Burkett LM, Kroll AJ, Thornton J, Mathews NE (2017) Factors associated with nest survival of Black-throated Sparrows, desert-breeding nest-site generalists. J Field Ornithol 88:274-287

Laake J, Rexstad E (2008) RMark-an alternative approach to building linear models in MARK: In Cooch E, White G (eds) Program MARK: a gentle introduction, Cornell University Press, Ithaca, NY. http://www.phidot.org/software/mark/docs/book/

Lakhanov DL (1977) Some features of the bird adaptation to life in the desert and the ecological analysis of their nesting period. Samarkand Univ Proc 324:33-49 (in Russian)

Lanovenko EN (1995) Turkestan Ground Jay. In: Birds of Uzbekistan, vol.3 Passeriformes, pp 129-134. Tashkent, Uzbekistan (in Russian)

Madge S (2009) Ground-jay Podoces species accounts. In: del Hoyo J, Elliott A, Christie DA (eds) Handbook of the Birds of the World. Lynx Edicions, Barcelona

Madge S, Burn H (1993) Crows and jays: a guide to the crows, jays and magpies of the world. Helm Information, Robertsbridge

Martin TE (1993) Nest predation among vegetation layers and habitat types: Revising the dogmas. Am Nat 141:897-913

Mayfield H (1975) Suggestions for calculating nesting success. Wilson Bull 87:456-466

Mezquida ET (2004) Nest site selection and nesting success of five species of passerines in a South American open Prosopis woodland. J Ornithol 145:16-22. https://doi.org/10.1007/s10336-003-0002-9

Pearce-Higgins JW, Brown DJ, Douglas DJT, Alves JA, Bellio M, Bocher P et al (2017) A global threats overview for Numeniini populations: synthesising expert knowledge for a group of declining migratory birds. Bird Conserv Int 27:6-34

R Core Team (2019) R: A language and environment for statistical computing. R Foundation for Statistical Computing, Vienna, Austria. URL https://www.R-project.org/

Radnezhad H, Satei N, Kaboli M, Karami M, Khorasani N, Prodon R, Abari MF, Cheraghi S (2011) Breeding ecology of the Iranian ground jay (Podoces pleskei). Afr J Biotechnol 10:4494-4500

Rustamov AK (1958) Birds of Turkmenistan, vol 2. Ashkhabad, Turkmenistan (in Russian)

Schaeffer T (2004) Video monitoring of shrub-nests reveals nest predators. Bird Study 51:170-177

Schmidt KA, Whelan CJ (1999) Nest placement and mortality: is nest predation a random event in space and time? Condor 101:916-920

Showler DA, Koshkin M, Burnside RJ, Dolman PM (2014) Breeding observations of and spring-summer habitat use by Turkestan Ground Jay Podoces panderi. BirdingASIA 22:107-111

Sih A, Englund G, Wooster D (1998) Emergent impacts of multiple predators on prey. Trends Ecol Evol 13:350-355

Staller EL, Palmer WE, Carroll JP, Thornton RP, Sisson DC (2005) Identifying predators at northern bobwhite nests. J Wildl Manag 69:124-132

Stevens DK, Anderson GQA, Grice PV, Norris K, Butcher N (2008) Predators of spotted flycatcher Muscicapa striata nests in southern England as determined by digital nest-cameras. Bird Study 55:179-187

Teunissen W, Schekkerman H, Willems F, Majoor F (2008) Identifying predators of eggs and chicks of Lapwing Vanellus vanellus and Black-tailed Godwit Limosa limosa in the Netherlands and the importance of predation on wader reproductive output. Ibis 150:74-85

Thompson FR III (2007) Factors affecting nest predation on forest songbirds in North America. Ibis 149:98-109

White GC, Burnham KP (1999) Program MARK: survival estimation from populations of marked animals. Bird Study 46:S120-S139

Zielonka NB, Hawkes RW, Jones H, Burnside RJ, Dolman PM (2020) Placement, survival and predator identity of Eurasian Curlew Numenius arquata nests on lowland grass-heath. Bird Study 66:471-483

Publisher's Note Springer Nature remains neutral with regard to jurisdictional claims in published maps and institutional affiliations. 